\title{
Environmental Protection Acts in India
}

\author{
Nishant Shyam Chavan
}

Assistant Professor, Mahatma Gandhi Vidyamandir Arts, Science and Commerce College Manmad. Tal: Nandgaon Dist: Nashik, Maharashtra, India

\section{Article Info}

Volume 8, Issue 5

Page Number : 480-483

\section{Publication Issue}

September-October-2021

\section{Article History}

Accepted : 16 Oct 2021

Published : 30 Oct 2021

\section{ABSTRACT}

The environment of our planet is degrading at an alarming rate because of non-sustainable urbanization, industrialization and agriculture. There is need of management of natural resources, biodiversity loss, land use, convention on biological diversity and ecosystem diversity. The rapid increase in industrialization and human needs, environment has been badly suffered. That why there was need of creating law for conversion of environment in India. So environmental laws made for huge to maintain an ecological balance of environment by safeguarding the forests and wildlife, biodiversity, forest conservation of the country. The ministry of environment forest $\&$ the nodal agency is the administrative structure of the central government for the planning, promotion, co-ordination and overseeing the implementation of environment\& forestry programmes. The principle activity taken by ministry of environment\& forest and wildlife prevention control of pollution, afforestation regeneration of degraded areas and protection of environment in the framework of legislation. This research paper will be focus on what has action $\&$ laws are made by Indian government for protection of environment.

Keywords : Environment law, Environment protection, Sustainable Development, Conservation, Welfare

"Earth provides enough to satisfy every man's needs, but not every man's greed."

-Mahatma Gandhi

\section{INTRODUCTION}

Word "environment" is most commonly used describing "natural" environment and means the sum of all living and non-living things that surround an organism, or group of organisms. Environment includes all elements, factors, and conditions that have some impact on growth and development of certain organism. Environment includes both biotic and a-biotic factors that have influence on observed organism. A-biotic factors such as light, temperature, water, atmospheric gases combine with biotic factors (all surrounding living species). Environment often changes after some time and therefore many 
organisms have ability to adapt to these changes. However tolerance range is not the same with all species and exposure to environmental conditions at the limit of a certain organism's tolerance range represents environmental stress. Environment is the immediate surrounding space around man. It includes a biotic and biotic component. So environment not only means our environment but also varies of issues connected with human activity and its impact on natural resources. It has been observed that in recent past far reaching changes have taken place. Man has played a key role in modifying the environment in his constant efforts towards improving the standard of living.

Environment Protection \& Legislation in India.

\section{$>$ Water Pollution:}

The Water (prevention and control of pollution) Act1974 amended 1988:

This was enacted to provide for the prevention and control of water pollution, and for the maintaining or restoring of wholesomeness of water in the country. The central and state pollution control board have been constituted under section 3 and 4 of the Act respectively.

The water (prevention and control of pollution) cess Act1977 amended 1992 and 2003:

This was enacted to provide for the levy and collection of a cess on water consumed by persons operating and caring type of industrial activites. These cess is collected with a view to augment the resources of the central board and the state board for the prevation and control of water pollution constituted under the water preventation ad control of pollution act 1974, The act was later amended in 2003

\section{$>$ Air Pollution:}

Air pollution -The Air (prevention and control of pollution) Act 1991. Amended 1987:

This is An Act to provide for the prevention, control and abatement of our pollution in the country so as the preserve the quality of air.

\section{Environment Protection.}

The environment (protection) Act 1986 amended 1991.

Against the backdrop of the United Nations Conference on the Human environment held at Stockholm in June 1972. In which India was a participant, the central gov't enacted a legislation, The Environment (protection Act) 1986', with the objective for protection and improvement of the environment and for matter connected with there with.

The power conferred by the Environment Protection Act is

1. Followed under the following head.

2. Coastal Regulation zone

3. Eco-marks scheme.

4. Eco- sensitive zone

5. Ozone layer depletion.

6. Water pollution

7. 2-Toil

8. Environment clearance

9. Environmental standards

10. Hazardous substances management

11. Loss of Ecology

12. Noise pollution

\section{Wildlife:}

The wild life Protection) Act, 1972, Amended1993, 2001 and 2006

This was called with the objective of effectively protecting the wild life of this country and to control poaching, so gling and illegal trade in wildlife and is derivatives. The ay amended in January 2003 and punishment and penalty for offences under the Act have been made more stringent.

\section{$>$ Forest conservation:}

Forest conservation Act 1980, Amended 1988:

In order to cheek rapid deforestation due to Forest lands being released by state government for 
agriculture, industry and other development, projects (allowed under Indian Forest Act) the central gov't enacted the forest conservation Act in 1980 with an amendment in 1988. The Act made the prior approval of the federal government necessary for dereservation of reserved forest, logging and for Use of forest land for non- forest Purpose. This powerful legislation has to a large extent, curtailed the indiscriminate logging and release of Forest land for non- forestry purpose by the state.

Indian Forest Act, 1927:

The main objective of the Indian Forest Act. 1924 ways to secure exclusive state control over forest to meet the demand for timber.

The scheduled Tribes and other Traditional Forest dweller (12 cognition of Forest Right) Act, 2006:

Dweller-A person that lives in or at a specified place.

$>$ Biodiversity:

Biological diversity Act, 2002:

Conservation of biological diversity, sustainable use of components. And four and equitable sharing of benefit arising from the Use of genetic resources.

\section{> National Green Tribunal:}

In 1995, the central government established the national-environment tribunal (through the National Environmental tribunal net 1995) to Provide for strict liability for damage arising out of Accidents from the handling of hazardous substances.

National Green Tribunal Act, 2010

Enacted expeditious disposal of cases relating to environment protection and conservation of forest and other natural resources including enforcement of any legal right relating to environment and giving relief and compensation for damage to person and property and for matters connected there with or incident there to.

Animal Welfare:

The prevention of cruelty to Animal Act, 1960
This was enacted in 1960 to prevent the infliction of unnecessary pain or suffering on animals and to amend the law relating to the prevention of cruelty to animals. After the Enactment of this Act, the Animal Board of India was formed for the promotion of animal welfare.

$>$ Central pollution control Board (CPCB) - 1974 .

Powers under the Act.

1. Water Act 1974

2. Air Act 1981

3. Environment Protection Act to 1986

\section{Principles of CPCB}

To promote "cleanliness of stresses and wells in different area of the states by prevention, control and abatement of Walter pollution

To improve the quality of air and to prevent control or abate air pollution in country.

> Kyoto protocol - 1997 Adopted to (UNFCC).

That aimed to reduce the emission of gases that contribute to global warming. In for since 2005. The protocol called for reducing the emission of six greenhouse gases in 41 countries plus the European Union to 5.2\%, below 1990 levels.

Commitment period 2009-12

1. Carbon dioxide $\left(\mathrm{CO}_{2}\right)$

2. Methane $(\mathrm{CH} 4)$

3. Nitrous oxide $\left(\mathrm{N}_{2} \mathrm{O}\right)$

4. Per fluorocarbons(PFCS)

5. Hydrofluoric carbons(HFCS)

6. Sulphur hexafluorkle (SFC)

$>$ Montreal protocol, 1987- To protect the ozone layer.

National solar mission.

Jawaharlal Nehru National Solar mission is also known as National solar mission, launched in 2010.

The Target of National solar mission.

20000 MW of gried-conected solar power by 2022 in 2015 it was revised to $100 \mathrm{GW}$ (100000 MW) by 2022 . 
$100 \mathrm{GW}$ solar powers divided into

1. Roof top solar electricity generation - $40 \mathrm{Gw}$

2. Large and medium scale grid-connected solar project -604

3. To deploy 20 million solar lighting system for rural areas by 2022 .

4. To 20 million sq. meter of solar thermal collectoral. Area by 2022.

\section{> The Biological Diversity Act 2002:}

The purpose of the Biodiversity Act is to realize equitable sharing of benefits arising out of the use of biological resources and associated knowledge. The main objectives of the Act are conservation, sustainable use and equitable benefit sharing out of the utilization of bio resources.

$>$ Hazardous Wastes (management and handling) Amendment Rules, 2003

1. Pact is close on regulation of ship recycling.

2. National inventory of hazardous wastes generating industries \& hazardous waste management in India.

3. Guidelines for environmentally sound management of e-waste.

4. Guidelines for environmentally sound management of e-waste.

$>$ National Environment policy - 2006:

The main aim of the national environment policy is conservation, prevention of degradation and equity of natural resources.

Main Environmental movement in India:

Chipko Movement:

1973 in Chamoll District Uttarakhand main leader shri sunderial Bahuguna.

Appiko movement:

1933 in the villages of Western Ghats in uttar Kannada region of karnataka.

Tehri Dam movement:

This movement was spearheaded by - Baba Amte against the submorgence of land by construction of dam. Population displacement among other environmental concerns. It started in 1970.

Save silent valley movement:

1973 in Palakkad district of kerla to save the silent valley Reserve Forest from being flooded, by a hydroelectric project. Silent valley national park in 1985.

Narmada Bachao Andolan:

Narmada valley project two mega project, such as sardar Sarovar project and Narmada sagar project in M.P. Main leader was Medha Patkar.

"What's the use of a fine house if you haven't got a tolerable planet to put it on?"

— Henry David Thoreau, Familiar Letters

\section{REFERENCES}

[1]. https://moef.gov.in

[2]. https://www.indiacode.nic.in

[3]. Lodha,S.L.(E.d)(1991),Environmental of Environment.RBSAPublishers,Jaipur

[4]. Karpagam,M.(1993),Environmental Economics,Sterling Publisher,New Delhi

[5]. Singh, G.N. (Ed.) (1991), Environmental Economics, Mittal Publication, New Delhi.

[6]. Mehta,C.S.(1994),Environment and Law,RBSA Publisher,New Delhi

\section{Cite this article as :}

Nishant Shyam Chavan, "Environmental Protection Acts in India", International Journal of Scientific Research in Science and Technology (IJSRST), Online ISSN : 2395-602X, Print ISSN : 2395-6011, Volume 8 Issue 5, pp. 480-483, September-October 2021. Available

doi $\quad$ : https://doi.org/10.32628/IJSRST218560

Journal URL : https://ijsrst.com/IJSRST218560 